\title{
Algae-Silica Hybrid Materials for Biosorption of Heavy Metals
}

\author{
Ulrich Soltmann ${ }^{1}$, Sabine Matys ${ }^{2}$, Gunter Kieszig $^{3}$, Wolfgang Pompe ${ }^{2}$, Horst Böttcher ${ }^{1}$ \\ ${ }^{1} G M B U$ e.V., Department of Functional Coatings, Dresden, Germany \\ ${ }^{2}$ Institute of Materials Science, Technical University Dresden, Dresden, Germany \\ ${ }^{3}$ WISUTEC GmbH, Chemnitz, Germany \\ E-mail:soltmann@gmbu.de \\ Received November 12, 2009; revised December 8, 2009; accepted December 14, 2009
}

\begin{abstract}
Algae-silica hybrid materials for biosorption purposes were prepared using sol-gel technology. The resulting biological ceramics (biocers) ought to combine the mechanical stability and porosity of the silicate matrix with the algae's capability for the biosorption for heavy metals. The structure, mechanical properties, and sorption capability of such algae-silicate materials were investigated. Comparative equilibrium sorption experiments were performed batchwise with 13 different microalgae and macroalgae powders, and the corresponding algae biocers using waters loaded with either concentrations of nickel below $3 \mathrm{mg} / \mathrm{L}$ or a mixture of different heavy metals $(\mathrm{Cr}, \mathrm{Ni}, \mathrm{Cu}, \mathrm{Pb})$. The algae biocers showed good mechanical stability up to an algae content of $30-50 \%$ and a total porosity of $40-60 \%$. The silica matrix itself was involved in the sorption of metals. The metal binding capability of embedded macroalgae biomass was unaffected by immobilisation in the silica matrix. In contrast, for waters with nickel or different heavy metals, reduced sorption capability was shown by embedded microalgae.
\end{abstract}

Keywords: Biosorption, Algae, Sol-Gel Process, Immobilisation, Heavy Metals, Biological Ceramics

\section{Introduction}

The removal of low concentrations of heavy metals from industrial wastewater and naturally occurring waters remains a problem, both technically and economically. For example, depending on local geology, many aquifers contain heavy metals such as nickel, uranium or arsenic in the lower $\mu \mathrm{g} / \mathrm{L}$ range, but sometimes in concentrations which cannot be tolerated for drinking water. Using the high biosorption capability exhibited by many algae [1-5], bacteria [6,7], and yeasts [8] might be a costeffective way of treating such waters.

The biosorption behaviour (selectivity and capacity) of a biocomponent depends on the composition of binding sites on its surface. Consequently, different biocomponents are suitable biosorptive materials for different water compositions. In this regard, algae appear very promising. Several micro- and macroalgae are commercially available on a large scale and at low cost. Since viability is not necessary for biosorption, dried algae or even algal extraction residues (by-products from the high-pressure extraction of valuable algal components) $[1,2]$ can be used as biosorptive material.

Biomass used for the sorption of heavy metals from waters in commercial applications must be immobilised in order to meet technical demands. Generally, packedbed columns are used, calling for a stable, porous material with a specific grain size. Moreover, immobilisation must prevent the release of biomass or of biomass compounds (e.g. dyestuffs).

The sol-gel technology offers a cost effective way to fulfill these requirements. In last years the use of sol-gel matrices for immobilizing biocomponents has attained increasing importance [9-13]. The sol-gel process is characterised by the aggregation and condensation of nanoparticles of silica or metal oxide sols, resulting in a lyogel and after drying in a xerogel. This solidification process can be used to embed biocomponents within the three-dimensional gel network. Combining a ceramiclike oxide matrix with biological systems ("biocers") offers important advantages. The mechanical, chemical, thermal and photochemical stability of the inorganic host matrix and the broad range of applicative forms of sol-gel derived materials (e.g., coatings, granules, shaped 
bulk products, extremely porous aerogels) make such biocomposites very promising for technical applications. The porosity and the degree of immobilisation of the embedded biocomponents can be controlled over a wide range. Depending on the preparation conditions, embedded biocomponents may be easily accessible to external reagents, and chemical reactions can proceed within the inorganic layer at high speed. So far, sol-gel matrices have been used to immobilise different types of living cells such as bacteria, yeasts, and plant or animal cells, and it has been demonstrated that they retain their bioactivity $[10,13-16]$. For biosorption purposes, the structure and metal-binding capacity of different types of sol- gel immobilised bacteria [17] and yeast [18,19] have been investigated with regard to their practical use for the selective and reversible accumulation of heavy metals and radionuclides.

This paper focuses on the use of silica sols for the embedding of algae biomass within stable and porous silica matrices, and on characterising the biosorption capabilities of such composites.

\section{Materials and Methods}

\subsection{Algae}

Algae were obtained as dried powders from the Institute for Cereal Processing (Nuthetal, Germany). The algae used are shown in Table 3.

\subsection{Silica Sols}

Nanosol A: 10mL TEOS (tetraethoxysilane, Fluka), $40 \mathrm{~mL}$ ethanol and $20 \mathrm{~mL} 0.01 \mathrm{~N} \mathrm{HCl}$ were stirred for $20 \mathrm{~h}$ at ambient temperature, resulting in an acidic nanosol with approximately $4.2 \%$ solid content.

Nanosol B: Nyacol 1440 (Akzo Nobel Chemicals Wurzen). This is an aqueous silica sol with $40 \%$ solid content and a mean particle diameter of $14 \mathrm{~nm}$.

Nanosol C: The sol was prepared by mixing $78 \mathrm{wt} \%$ Nyacol 1440 (Nanosol B) with an organically modified sol D $(22 \mathrm{wt} \%)$.

Nanosol D: 52g TEOS, 69.5g GLYEO ((3-glycidyloxy propyl)triethoxysilane, Fluka), $150 \mathrm{~mL} 0.01 \mathrm{M} \mathrm{HCl}$ and $150 \mathrm{~mL}$ ethanol were stirred for $20 \mathrm{~h}$ at ambient temperature, resulting in an acidic nanosol with a solid content of approximately $8.4 \%$.

\subsection{Preparation of Algae Biocers}

Algae biocers were produced by mixing the nanosols A$\mathrm{C}$ with algae mass which had been pre-washed in deionised water. Before mixing, the sol was adjusted to about
$\mathrm{pH}$ 7. After neutralisation the gelling occurred rapidly, embedding the algae within the silica matrix. The algae contents were $20 \%\left(\mathrm{wt} / \mathrm{wt} \mathrm{SiO}_{2}\right)$. In some cases, algae content up to $50 \%$ was used. The gels were aged for 3 days at $4^{\circ} \mathrm{C}$, then cut into small pieces, dried, and sieved to give particles with a size of approximately $0.5-1.2 \mathrm{~mm}$. Those algae biocers made from nanosols $\mathrm{B}$ or $\mathrm{C}$ were heated for $1 \mathrm{~h}$ at $120^{\circ} \mathrm{C}$ after gelling and drying.

\subsection{Sorption Experiments}

Comparative equilibrium sorption experiments were performed batchwise with different algae and algae biocers that had been double washed in $\mathrm{H}_{2} \mathrm{O}$ beforehand. The non-immobilised algae and the biocers $(30-1000 \mathrm{mg})$ were shaken for $24 \mathrm{~h}$ at $30^{\circ} \mathrm{C}$ in a volume of 30 or 300 $\mathrm{mL}$. Nickel sorption experiments were carried out in drinking waters $(\mathrm{pH} 7)$ with initial concentrations of 1.7 or $2.2 \mathrm{mg} / \mathrm{L}$. For experiments with a mixture of copper, nickel, chromium and lead, the initial concentration of each metal was $0.2 \mathrm{mM}$. $\mathrm{pH}$ was adjusted to 4.5 to avoid precipitation.

The residual metal concentrations were determined by inductively coupled plasma mass spectroscopy (ICPMS).

\subsection{Characterisation of the Biocers}

Pore size distribution was measured by mercury intrusion (Pascal 140 and 440, Porotec) which evaluates pore diameters in the range of $4 \mathrm{~nm}$ to $100 \mu \mathrm{m}$.

To characterise particle stability, aliquots of $5 \mathrm{~mL}$ biocer material with a grain size between $400-600 \mu \mathrm{m}$ were exposed to different compressive forces $(3,5,7$, and $9 \mathrm{kN})$ in a stainless steel cylinder, inner diameter $25 \mathrm{~mm}$ and height $90 \mathrm{~mm}$. The compressed material was retained by a loosely fitted steel cap on the bottom of the cylinder. Compression assays were carried out with a compression testing machine LP1 (Heckert Werke, Germany). After compression the biocers were subjected to sieve analysis.

The structures of the biocers were monitored by light microscopy (Keyence VHX-100 digital microscope) and by scanning electron microscopy. For the latter, the samples were embedded in liquid colloidal silver on conductive carbon sheets. After shadow casting with carbon (Baltec MED 010, BAL-TEC, Liechtenstein), the biocers were examined using a Gemini 982 scanning electron microscope (LEO, Oberkochen) with an energy dispersive X-ray analyser (NORAN X-ray detector) at $1-5 \mathrm{kV}$.

Polished specimens were produced by embedding the biocer particles within epoxy resin, which then underwent fractionated grinding with abrasive paper of different grain sizes and polishing with a diamond suspension of $6 \mu \mathrm{m}$ particles. 


\section{Results and Discussions}

\subsection{Preparation and Properties of the Algae Biocers}

The immobilisation matrix has to fulfil partly contradictory requirements. It must have good mechanical stability, high porosity, safe immobilisation, good accessibility of the binding groups of the biocomponents, and allow cost-effective production on a large scale.

Two silica-sol variants were tested for algae immobilisation: a sol prepared by the acid-catalysed hydrolysis of tetraethyl orthosilicate (TEOS, sol A), and the commercially available $\mathrm{Nyacol}^{\circledR}$ (sol B). Nanosols produced from aqueous sodium silicate using ion exchange techniques are very cost effective. Diverse aqueous dispersions of colloidal polysilic acid are commercially available, e.g. Nyacol ${ }^{\circledR} /$ Akzo Nobel, Ludox ${ }^{\circledR} /$ Grace, Levasil $^{\circledR} /$ Bayer, and Köstrosol ${ }^{\circledR} /$ Chemiewerke Bad Köstritz. To prepare the biocers, the silica sol was neutralised. Then the algae were admixed into it by vigorous shaking. Neutralisation promotes the sol-gel transition that results in the embedding of the algae biomass within the inorganic network. Dried and, in the case of macroalgae, ground biomass was used in preparing the biocer. Once solid, the gels were cut into small pieces and dried. Air-drying resulted in noticeable shrinkage of the silica network, with the formation of a hard, non-compressible material. Before performing the experiments, the biocers were sieved to a particle size of $0.5-1.2 \mathrm{~mm}$ (Figure 1).

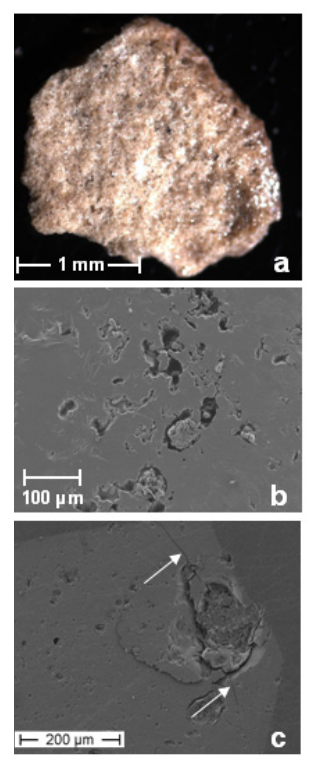

Figure 1. (a) Microscope picture of a Fucus biocer particle. (b) Cross-section (SEM micrograph, polished specimen) of a Spirulina biocer. (c) Cross-section of a Spirulina biocer (polished specimen). The arrows mark cracks starting from aggregated Spirulina platensis algae.
Table 1. Percentage of different particle size classes for different algae-biocers after compression at distinct forces.

\begin{tabular}{clcccc}
\hline Sample & particle size class & \multicolumn{4}{c}{ compressive force $(\mathrm{kN})$} \\
\hline \multicolumn{1}{c}{$\mu \mathrm{m}$} & 3 & 5 & 7 & 9 \\
\hline \multirow{2}{*}{ Fucus biocer } & $>0$ up to $\leq 200$ & 15 & 17 & 24 & 24 \\
(sol B) & $>200$ up to $\leq 400$ & 19 & 26 & 23 & 24 \\
& $>400$ & 66 & 57 & 53 & 52 \\
\hline \multirow{2}{*}{ Spirulina } & $>0$ up to $\leq 200$ & 9 & 16 & 19 & 14 \\
biocer (sol B) & $>200$ up to $\leq 400$ & 16 & 20 & 21 & 26 \\
& $>400$ & 75 & 64 & 60 & 60 \\
\hline \multirow{2}{*}{ Fucus biocer } & $>0$ up to $\leq 200$ & 7 & 11 & 14 & 17 \\
(sol A) & $>200$ up to $\leq 400$ & 10 & 14 & 15 & 18 \\
& $>400$ & 83 & 75 & 71 & 65 \\
\hline \multirow{2}{*}{ Spirulina } & $>0$ up to $\leq 200$ & 5 & 7 & 11 & 14 \\
biocer (sol A) & $>200$ up to $\leq 400$ & 10 & 12 & 16 & 17 \\
& $>400$ & 85 & 81 & 73 & 69 \\
\hline
\end{tabular}

Homogeneous distribution of the embedded algae within the silica matrix was crucial for the mechanical stability of the resulting biocers. Aggregated algae promoted crack formation (Figure 1(c)). Adding the coating additive Addid $^{\circledR} 200$ (Wacker-Chemie GmbH, Munich, Germany), a polyether-modified polysiloxane, to the silica sol improves the uniformity of the algae distribution.

To evaluate the mechanical stability of the prepared algae biocers, changes in the particle size distribution were noted after agitation in water for 24 hours. It was shown that biocers made with Nyacol broke up into smaller particles, as a result of swelling of the embedded algae after wetting. In particular, biocers with macroalgae powder showed reduced stability due to their swelling behaviour and larger particle size of about 100-400 $\mu \mathrm{m}$. Matrix stability could be sufficiently enhanced by heating the biocers for one hour at $120^{\circ} \mathrm{C}$, and by the admixture of a GLYEO ((3-glycidyloxypropyl)triethoxysilane) modified sol (sol C). Using the Nyacol-based sol $\mathrm{C}$, mechanically stable biocers could be made with a microalgae content up to $50 \%\left(\mathrm{wt} / \mathrm{wt} \mathrm{SiO}_{2}\right)$, or $30 \%$ in the case of macroalgae.

Further demonstrating mechanical stability, Table 1 shows the particle size distribution of algae biocers after compression experiments with different forces. The starting material had a grain size of $400-600 \mu \mathrm{m}$.

The compression experiments revealed the stability of the dry bulk material. More than $50 \%$ of the particles remained unchanged in size (detected by the fraction greater than $400 \mu \mathrm{m}$ ) for each of the samples under investigation, even after exposure to $9 \mathrm{kN}$ pressure force. Generally, the two samples prepared by using sol A were more stable than those with Nyacol, as indicated by the greater fractions of unbroken particles.

Shrinkage of the gel matrix during drying resulted in a compaction of the embedded biocomponents and decreasing porosity of the biocer material. The shrinkage, 
pore structure and rigidity of the matrix could be controlled by the $\mathrm{SiO}_{2}$ solid content, the drying regime (e.g. air- or freeze-drying), the residual water content, the addition of fillers (e.g. ceramic fibres) [20], or by the leaching of admixed pore-forming additives [21,22]. Also, the structure and size of the embedded biocomponents were crucial to the exhibited porosity. Mercury intrusion was used to evaluate the pore diameters of dry algae biocers in the range of $4 \mathrm{~nm}$ to $100 \mu \mathrm{m}$. Figure 2 shows the pore size distribution of Fucus biocers made by using sol variants $\mathrm{A}$ and B. Biocers based on sol B showed higher total porosity with a high quantity of mesopores in the range of $10 \mathrm{~nm}$. The embedded Fucus vesiculosus biomass presumably caused the exhibited macroporosity. A similar pore distribution was also shown by Chlorella vulgaris biocers (Table 2); although the total porosity was marginally lower. However, total porosity between $38 \%$ and $60 \%$ allowed a good mass transfer.

\subsection{Biosorption of Nickel by Different Algae and Algae Biocers}

To examine how embedding algae within a silica matrix affects their metal-binding capability, non-immobilised
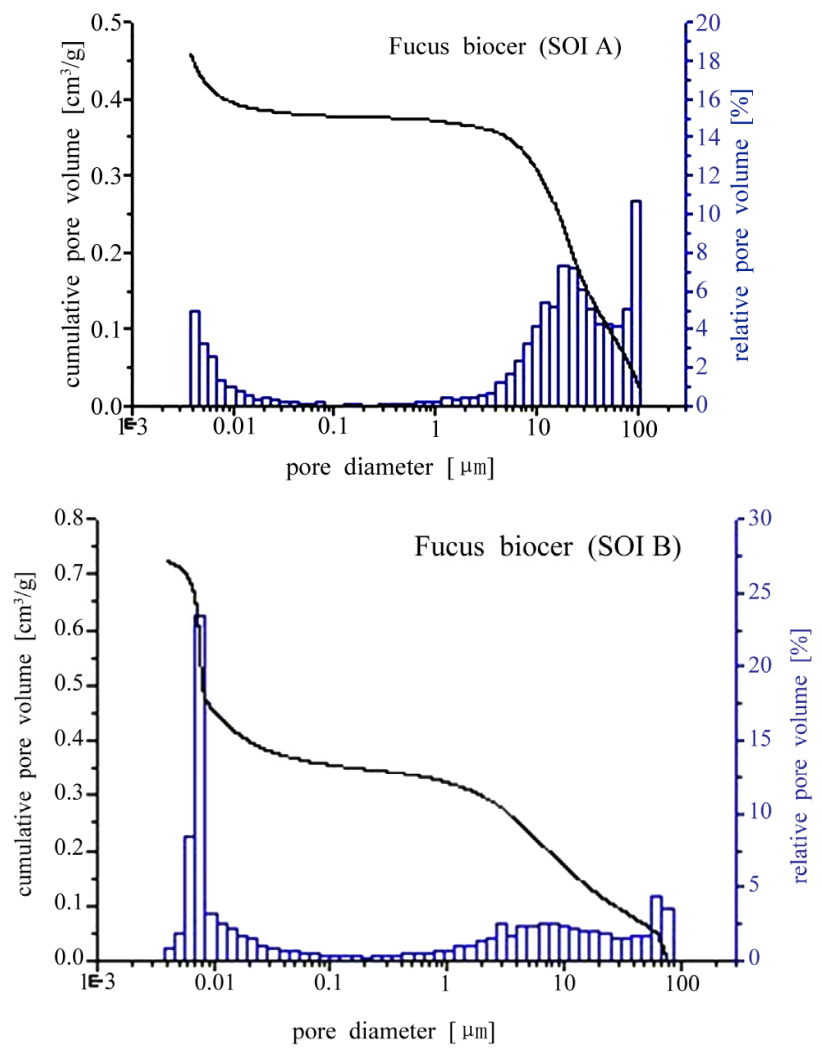

Figure 2. Pore size distribution in two Fucus biocer variants prepared using sol A or sol B. Columns $=$ relative pore volume, curve $=$ cumulative pore volume.
Table 2. Porosity of Fucus and Chlorella biocers prepared using sol A or sol B.

\begin{tabular}{ccccc}
\hline & \multicolumn{2}{c}{ Fucus biocers } & \multicolumn{2}{c}{ Chlorella biocers } \\
\hline & $\begin{array}{c}\text { Sol A } \\
\text { biocer }\end{array}$ & $\begin{array}{c}\text { Sol B } \\
\text { biocer }\end{array}$ & $\begin{array}{c}\text { Sol A } \\
\text { biocer }\end{array}$ & $\begin{array}{c}\text { Sol B } \\
\text { biocer }\end{array}$ \\
\hline $\begin{array}{c}\text { Total cumulative } \\
\text { volume (cc/g) }\end{array}$ & 0,4595 & 0,7240 & 0,3697 & 0,6645 \\
$\begin{array}{c}\text { Total porosity } \\
(\%)\end{array}$ & 43,9 & 60,2 & 37,8 & 57,7 \\
$\begin{array}{c}\text { Bulk density } \\
\left(\mathrm{g} / \mathrm{cm}^{3}\right)\end{array}$ & 0,9558 & 0,8314 & 1,0233 & 0,8687 \\
$\begin{array}{c}\text { Apparent density } \\
\left(\mathrm{g} / \mathrm{cm}^{3}\right)\end{array}$ & 1,7042 & 2,0883 & 1,6459 & 2,0550 \\
\hline
\end{tabular}

Table 3. Biosorption of nickel by different algae.

\begin{tabular}{lcc}
\hline \multicolumn{1}{c}{ Algae } & \multicolumn{2}{c}{ Bound Ni } \\
\hline Scenedesmus obliquus & $\%$ & $\mathrm{mg} / \mathrm{g}$ \\
Kelp & 60 & 0.80 \\
Laminaria saccharina & 48 & 0.64 \\
Chlorella vulgaris & 46 & 0.61 \\
Laminaria digitata & 43 & 0.58 \\
Ascophyllum nodosum & 41 & 0.55 \\
Nannochloropsis oculata & 39 & 0.52 \\
Haematococcus pluvialis & 38 & 0.51 \\
Fucus vesiculosus & 36 & 0.48 \\
Spirulina platensis & 31 & 0.41 \\
Scytonema hofmanni & 29 & 0.38 \\
Porphyridium cruentum & 27 & 0.36 \\
Dunaliella salina & 20 & 0.27 \\
\hline
\end{tabular}

algae and algae biocers were tested. Nickel contaminated waters and a solution of different heavy metals were used for comparative sorption experiments.

The nickel sorption capabilities of the selected algae were tested under equilibrium conditions (contact time $24 \mathrm{~h}$ ) using drinking water loaded with $2.2 \mathrm{mg} \mathrm{Ni}^{2+} / \mathrm{L}$. To reveal sorption capability differences between the algae, the algae/nickel ratio was selected so that only part of the offered nickel would be removed. A total of $1.34 \mathrm{mg}$ was offered per gram of algae. Table 3 shows the results of the equilibrium sorption experiments. Best results were shown by the microalgae Scenedesmus and Chlorella and the phaeophyceae Kelp and Laminaria.

To examine to what extent nickel binding was influenced by immobilising the algae in a silica matrix, the nickel sorption capability of algae, algae biocers, and the silica matrix were tested with respect to the quantity of the adsorbent. For these tests 20,40 , or $100 \mathrm{mg}$ algae or algae biocers were exposed to $250 \mathrm{~mL}$ of a $1.7 \mathrm{mg} / \mathrm{L}$ 
nickel solution for $24 \mathrm{~h}$ (Table 4).

C. vulgaris and $S$. platensis algae and biocers have shown a linear correlation, with nearly the same gradient between the amount of algae or biocer used and the resulting nickel concentration. Due to the algae content of the biocers, $100 \mathrm{mg}$ biocer granules contained approximately $17 \mathrm{mg}$ algae biomass. The silica matrix itself possessed a good nickel sorption. On the basis of the results for $20 \mathrm{mg}$ non-immobilised algae and $100 \mathrm{mg}$ silica a theoretical nickel binding of $197 \mu \mathrm{g} / 100 \mathrm{mg}$ for Chlorella biocers and $183 \mu \mathrm{g} / 100 \mathrm{mg}$ for Spirulina biocers can be calculated. This means that by Chlorella biocers $62 \%$ and Spirulina biocers $75 \%$ of the theoretical values were reached. The reason is probably a mutual blockage of adsorption places by these algae and the silica matrix.

A reduced biosorption capability of microalgae after immobilisation was also observed by others. For example Rangsayatorn et al. [23] studied the biosorption of cadmium by Spirulina platensis immobilised by using alginate or sodium silicate. They showed that after immobilisation the maximum biosorption capacities were reduced to $38 \%$ in case of silica immobilised algae and $72 \%$ by using alginate. Similar results were reported by Mahan $\&$ Holcombe [24] for algae immobilised on silica gel. By comparison of the extrapolated saturation values for free and immobilised algae they observed a $40 \%$ loss of adsorption efficiency as a result of the immobilisation. Wong
\& Pak [25] used alginate for immobilisation of four Chlorella strains. They also reported reduced removal efficiencies for copper and nickel after immobilisation.

The ground macroalgae biomass of Fucus vesiculosus and Kelp showed no or only a slight decrease of the residual nickel concentration for an increasing amount of algae biomass used. The tendency of the used $F$. vesiculosus and Kelp powder to agglomerate at higher biomass contents could be responsible for these results. However, after homogeneously embedding the macroalgae in the silica matrix, enhanced nickel sorption was observed. This could be explained by a better disposability of the algae surface while preventing the agglomeration tendency. Approximately $114 \%$ of the calculated theoretical binding capacity was reached by the Fucus and Kelp biocers.

\subsection{Biosorption of $\mathrm{Cr}, \mathrm{Ni}, \mathrm{Cu}$ and $\mathrm{Pb}$ from a Mixed Solution}

To evaluate the biosorption behaviour of different algae in the presence of several heavy metals, sorption experiments were carried out in a system containing copper, nickel, and chromium and lead ions. An aqueous solution with $0.2 \mathrm{mM}$ of each of the metal ions was used, and $\mathrm{pH}$ was adjusted to 4.5 to avoid precipitation. Table 5 shows the results of the biosorption experiments.

Table 4. Removal of nickel from solution by algae and algae biocers with respect to quantity.

\begin{tabular}{|c|c|c|c|c|c|c|c|c|c|}
\hline & \multicolumn{3}{|c|}{$20 \mathrm{mg}$} & \multicolumn{3}{|c|}{$40 \mathrm{mg}$} & \multicolumn{3}{|c|}{$100 \mathrm{mg}$} \\
\hline & $\mathrm{mg} / \mathrm{L}^{a}$ & $\mu g^{b}$ & $\%^{c}$ & $\mathrm{mg} / \mathrm{L}$ & $\mu \mathrm{g}$ & $\%$ & $\mathrm{mg} / \mathrm{L}$ & $\mu \mathrm{g}$ & $\%$ \\
\hline Chlorella vulgaris & 1.43 & 56 & 14 & 1.32 & 85 & 21 & 1.12 & 136 & 33 \\
\hline Spirulina platensis & 1.47 & 39 & 10 & 1.36 & 65 & 16 & 1.15 & 118 & 29 \\
\hline Fucus vesiculosus & 1.03 & 139 & 35 & 1.06 & 132 & 33 & 1.03 & 138 & 35 \\
\hline Kelp & 0.96 & 153 & 39 & 0.83 & 186 & 47 & 0.77 & 202 & 51 \\
\hline Chlorella biocer & 1.58 & 45 & 10 & 1.51 & 62 & 14 & 1.27 & 123 & 28 \\
\hline Spirulina biocer & 1.59 & 49 & 11 & 1.48 & 76 & 17 & 1.24 & 137 & 31 \\
\hline Fucus biocer & 1.28 & 109 & 26 & 1.04 & 168 & 39 & 0.50 & 305 & 71 \\
\hline Kelp biocer & 1.31 & 106 & 24 & 1.05 & 173 & 40 & 0.47 & 317 & 73 \\
\hline Silica matrix & 1.65 & 29 & 7 & 1.59 & 44 & 10 & 1.04 & 181 & 41 \\
\hline
\end{tabular}

${ }^{a}$ Remaining nickel concentration. ${ }^{b}$ Bound nickel in $\mu \mathrm{g} .{ }^{c}$ Removal of nickel from solution in $\%$.

Table 5. Biosorption of $\mathrm{Cr}, \mathrm{Ni}, \mathrm{Cu}$, and $\mathrm{Pb}$ by different algae.

\begin{tabular}{|c|c|c|c|c|c|}
\hline & \multicolumn{5}{|c|}{ [ $\mu \mathrm{mol} / 200 \mathrm{mg}$ algae $\mathrm{dw}]$} \\
\hline & $\mathrm{Cr}$ & $\mathrm{Ni}$ & $\mathrm{Cu}$ & $\mathrm{Pb}$ & $\Sigma$ \\
\hline L. saccharina & 5.32 & 5.26 & 7.50 & 6.92 & 25.00 \\
\hline F. vesiculosus & 5.00 & 4.96 & 7.46 & 6.96 & 24.38 \\
\hline S. obliquus & 5.74 & 3.32 & 7.88 & 7.08 & 24.02 \\
\hline P. cruentum & 5.52 & 2.80 & 7.62 & 6.92 & 22.86 \\
\hline C. vulgaris & 5.72 & 3.52 & 6.48 & 7.00 & 22.72 \\
\hline S. platensis & 5.38 & 0.56 & 6.40 & 6.20 & 18.54 \\
\hline S. hofmanni & 5.02 & 0.56 & 5.18 & 6.12 & 16.88 \\
\hline H. pluvialis & 3.84 & 0.40 & 4.48 & 6.12 & 14.84 \\
\hline Total offered & 5.82 & 5.68 & 7.98 & 7.08 & 26.56 \\
\hline
\end{tabular}


Best results were attained by the brown marine algae $L$. saccharina and $F$. vesiculosus which removed nearly all of the offered metals under the test conditions. Even recalcitrant metals such as $\mathrm{Ni}$ were removed to a high degree. In contrast, the microalgae showed a lower $\mathrm{Ni}$ sorption capability.

To estimate the effect of immobilisation on the biosorption behaviour of the embedded algae biomass, non-immobilised algae were compared with algae embedded in a silicate matrix (Table 6).

In the case of the marine macroalgae $F$. vesiculosus and $L$. saccharina, no adverse effect to their metal binding capability was visible as a result of immobilisation in the silica matrix. By contrast, the sorption capability of the embedded microalgae $P$. cruentum, $C$. vulgaris and $S$. obliquus was clearly reduced after immobilisation.

Differences in the sorption capability of different biocers were confirmed after higher loading of the algae biocers. For this purpose the algae biocers were exposed four times to the solution containing heavy metals. About $30 \mu \mathrm{mol} / \mathrm{g}$ of each metal were offered. Table 7 shows the results.

The best metal-binding properties were shown by the Laminaria and Fucus biocers. These removed about $78 \%$ and $71 \%$ respectively of the total offered metals. The microalgae biocers take up $\mathrm{Cr}$ preferentially, with relatively low removal rates for $\mathrm{Ni}, \mathrm{Cu}$, and $\mathrm{Pb}$. The silica matrix itself is only involved in the sorption of $\mathrm{Cr}$ under the given conditions.

\section{Conclusions}

By use of silica nanosols different microalgae and macroalgae powders were successfully immobilised within granular silica gel matrices. The dry gels were mechanical stable and could be grounded to smaller particle sizes. The stability of the granules in water depends strongly on the biomass content, and the size and distribution of the biocomponents. TEOS based biocers showed the highest stability. Nevertheless, even in Nyacol based biocers microalgae contents up to $50 \%$ (wt/wt $\mathrm{SiO}_{2}$ ), or $30 \%$ in the case of macroalgae, could be realized using the GLYEO modified sol variant $\mathrm{C}$ or heat treatment. Using commercially available nanosols like Nyacol a very cost effective production of algae biocers is possible. The biocers had shown a total porosity up to $60 \%$ allowing a good accessibility of the embedded biocomponents. By the sorption experiments no adverse effect on the sorption capability was visible in case of

Table 6. The effectiveness of different algae and algae biocers in removing heavy metals from a solution containing $\mathrm{Cr}$, $\mathrm{Ni}$, $\mathrm{Cu}$, and $\mathbf{P b}^{a}$.

\begin{tabular}{lcccccccc}
\hline & \multicolumn{4}{c}{ Removing heavy metals from solution by sorption onto algae or algae biocers [\%] } \\
\cline { 2 - 8 } & \multicolumn{3}{c}{ non-immobilised algae } & \multicolumn{3}{c}{ algae biocers } \\
\cline { 2 - 9 } & $\mathrm{Cr}$ & $\mathrm{Ni}$ & $\mathrm{Cu}$ & $\mathrm{Pb}$ & $\mathrm{Cr}$ & $\mathrm{Ni}$ & $\mathrm{Cu}$ & $\mathrm{Pb}$ \\
\hline L. saccharina & 92 & 93 & 94 & 98 & 99 & 99 & $>99.5$ & $>99.5$ \\
F. vesiculosus & 86 & 88 & 94 & 98 & 99 & 97 & 99 & 99 \\
P. cruentum & 95 & 49 & 95 & 98 & 91 & 25 & 62 & 63 \\
C. vulgaris & 98 & 62 & 81 & 99 & 96 & 19 & 57 & 57 \\
S. obliquus & 99 & 59 & 99 & 100 & 50 & 3 & 24 & 16 \\
Silica-matrix & & & & & 62 & 4 & 2 & 1 \\
\hline
\end{tabular}

${ }^{a}$ The water at $\mathrm{pH} 4.5$ contained $0.2 \mathrm{mmol} / \mathrm{L}$ of each metal. $200 \mathrm{mg}$ algae (dw) or $1 \mathrm{~g}$ granulate biocer material (equivalent to $200 \mathrm{mg}$ immobilised algae) were exposed to approx. $7 \mu \mathrm{mol}$ of each metal.

Table 7. Removal of heavy metals by different algae-biocers ${ }^{\mathrm{a}}$.

\begin{tabular}{lccccc}
\hline & & bound metal in $\mathrm{mg} / \mathrm{g}$ biocer & & $\begin{array}{c}\text { total bound metal } \\
\mu \text { mol/g biocer }\end{array}$ \\
\cline { 2 - 5 } & $\mathrm{Cr}$ & $\mathrm{Ni}$ & $\mathrm{Cu}$ & $\mathrm{Pb}$ & 89.91 \\
\hline Laminaria biocer & 1.444 & 0.677 & 1.445 & 5.776 & 81.54 \\
Fucus biocer & 1.418 & 0.550 & 1.139 & 5.589 & 31.21 \\
Porphyridium biocer & 0.976 & 0.119 & 0.348 & 1.026 & 31.12 \\
Chlorella biocer & 1.040 & 0.099 & 0.323 & 0.900 & 16.36 \\
$\mathrm{Scenedesmus} \mathrm{biocer}_{\mathrm{SiO}_{2} \text { granules }}$ & 0.518 & 0.063 & 0.207 & 0.429 & 12.49 \\
Total offered & 0.517 & 0.066 & 0.036 & 0.177 & 115.50 \\
\hline
\end{tabular}

${ }^{\mathrm{a}} 1 \mathrm{~g}$ biocer material was exposed to approximately $30 \mu \mathrm{mol}$ of each metal. 
embedded macroalgae biomass. In contrast, immobilised microalgae showed a reduced binding of nickel, copper and lead, as expected on basis of the results for nonimmobilised algae and the silica matrix. The silica matrix itself was involved into the metal binding.

Overall, the use of silica nanosols for the production of granular algae-silica hybrid materials is a promising way to integrate biosorption capabilities of algae-biomass into the conventional technical equipment of water treatment plants. To overcome still existing uncertainties by embedding of microalgae in shape of reduced binding of heavy metals, further investigations in the composition of the immobilisation matrix are necessary. On the base of appropriate chemical modifications, the preservation of the binding capability of the embedded biocomponent as well as the exploration of synergistic effects by providing additional binding sites on the immobilisation matrix itself is aspired.

\section{Acknowledgments}

We thank the Department of Ceramic Materials and Components, University of Bremen, for help in performing the pore distribution measurements. Financial support from the German Federal Ministry for Economy and Labour (INNO-WATT program IW041148) is gratefully acknowledged.

\section{References}

[1] E. Sandau, P. Sandau, O. Pulz, and M. Zimmermann, "Heavy metal sorption by marine algae and algal by-products," Acta Biotechnologica, Vol. 16, pp.103-119, 2004

[2] E. Sandau, P. Sandau, and O. Pulz, "Heavy metal sorption by microalgae," Acta Biotechnologica, Vol. 16, pp. 227235, 2004

[3] J. Yang and B. Volesky, "Biosorption of uranium on Saragassum biomass," Water Resources, Vol. 33, No. 15, pp. 3357-3363, 1999.

[4] S. K. Mehta and J. P. Gaur, "Use of algae for removing heavy metal ions from wastewater: Progress and prospects," Critical Reviews in Biotechnology, Vol. 25, pp. 113-152, 2005.

[5] S. Klimmek, H. J. Stan, A. Wilke, G. Bunke, and R. Buchholz, "Comparative analysis of the biosorption of cadmium, lead, nickel, and zinc by algae," Environmental Science \& Technology, Vol. 35, pp. 4283-4288, 2001.

[6] G. M. Gadd and C. White, "Microbial treatment of metal pollution: A working biotechnology?" Trends in Biotechnology, Vol. 11, No. 8, pp. 353-359, 1993.

[7] S. Selenska-Pobell, P. Panak, V. Miteva, I. Boudakov, G. Bernhard, and H. Nitsche, "Selective accumulation of heavy metals by three indigenous Bacillus strains, $B$. cereus, B. megaterium and $B$. sphaericus, from drain waters of a uranium waste pile," FEMS Microbiology Ecology, Vol. 29, pp. 59-67, 1999.
[8] N. B. Omar, M. L. Merroun, M. T. Gonzales-Munoz, and J. M. Arias, "Brewery yeast as a biosorbent for uranium," Journal of Applied Bacteriology, Vol. 81, pp. 283-287, 1996.

[9] G. Carturan, R. Campostrini, S. Dirè, V. Scardi, and E. De Alteriis, "Inorganic gels for immobilization of biocatalysts: Inclusion of invertase-active whole cells of yeast ( $\mathrm{Sac}$ charomyces cerevisiae) into thin layers of $\mathrm{SiO}_{2}$ gel deposited on glass sheets," Journal of Molecular Catalysis, Vol. 57, pp. L13-L16, 1989.

[10] H. Böttcher, "Bioactive sol-gel coatings," Journal für Praktische Chemie, Vol. 342, pp. 427-436, 2000.

[11] I. Gill, "Bio-doped nanocomposite polymers: Sol-gel bioencapsulates," Chemistry of Materials, Vol. 13, pp. 3404-3421, 2001.

[12] D. Avnir, T. Coradin, O. Lev, and J. Livage, "Recent bio-applications of sol-gel materials," Journal of Materials Chemistry, Vol. 16, pp. 1013-1030, 2006.

[13] T. Coradin and J. Livage, "Aqueous silicates in biological sol-gel applications: New perspectives for old precursors," Accounts of Chemical Research, Vol. 40, pp. 819-826, 2007.

[14] H. Böttcher, U. Soltmann, M. Mertig, and W. Pompe, "Biocers: Ceramics with incorporated microorganisms for biocatalytic, biosorptive and functional materials development," Journal of Materials Chemistry, Vol. 14, pp. 2176-2188, 2004.

[15] G. Carturan, R. Dal Toso, S. Boninsegna, and R. Dal Monte, "Encapsulation of functional cells by sol-gel silica: Actual progress and perspectives for cell therapy," Journal of Materials Chemistry, Vol. 14, pp. 2087-2098, 2004.

[16] B. Samuneva, P. Djambaski, E. Kashchieva, G. Chernev, L. Kabaivanova, E. Emanuilova, I. M. Miranda Salvado, M. H. V. Fernandes, and A. Wu, "Sol-gel synthesis and structure of silica hybrid biomaterials," Journal of Non-Crystalline Solids, Vol. 354, pp. 733-740, 2008.

[17] J. Raff, U. Soltmann, S. Matys, S. Selenska-Pobell, H. Böttcher, and W. Pompe, "Biosorption of uranium and copper by biocers," Chemistry of Materials, Vol. 15, pp. 240-244, 2003.

[18] S. Marseaut, A. Debourg, P. Dostalek, J. Votruba, G. Kuncova, and J. M. Tobin, "A silica matrix biosorbent of cadmium," International Biodeterioration \& Biodegradation, Vol. 54, pp. 209-214, 2004.

[19] M. Al-Saraj, M. S. Abdel-Latif, I. El-Nahal, and R. Baraka, "Bioaccumulation of some hazardous metals by sol-gel entrapped micro-organisms," Journal of Non-Crystalline Solids, Vol. 248, pp. 137-140, 1999.

[20] D. Fiedler, A. Thron, U. Soltmann, and H. Böttcher, "New packing materials for bioreactors based on coated and fiber-reinforced biocers," Chemistry of Materials, Vol. 16, pp. 3040-3044, 2004.

[21] U. Künzelmann and H. Böttcher, "Biosensor properties of glucose oxidase immobilized within $\mathrm{SiO}_{2}$ gels," Sensors and Actuators B, Vol. 38-39, pp. 222-228, 1997.

[22] Y. Wei, J. Xu, H. Dong, J. H. Dong, K. Qiu, and S. A. Jansen-Varnum, "Preparation and physisorption charac- 
terization of d-glucose-templated mesoporous silica sol-gel materials," Chemistry of Materials, Vol. 11, pp. 2023-2029, 1999.

[23] N. Rangsayatorn, P. Pokethitiyook, E. S. Upatham, and G. R. Lanze, "Cadmium bio-sorption by cells of Spirulina platensis TISTR 8217 immobilized in alginate and silica gel," Environment International, Vol. 30, pp. 57-63, 2004.
[24] C. A. Mahan and J. A. Holcombe, "Immobilization of algae cells on silica gel and their characterization for trace metal pre-concentration," Analytical Chemistry, Vol. 64, pp. 1933-1939, 1992.

[25] M. H. Wong and D. C. Pak, "Removal of copper and nickel by free and immobilized microalgae," Biomedical and Environmental Sciences, Vol. 5, pp. 99-108, 1992. 